\title{
EVIDENCE OF HANTAVIRUS EXPOSURE IN RODENTS FROM NORTH TEXAS
}

\author{
Richard M. Pitts ${ }^{1}$, Matthew R. Mauldin 2,4 , Cody W. Thompson ${ }^{2}$, and Jerry R. Choate ${ }^{3}$
}

\begin{abstract}
Aвstract.-Between 27 June 1997 and 16 May 1999, 423 rodents were collected from North Texas (Collin, Denton, and Grayson counties) by using Sherman live-traps (trapping success rate $\sim 22 \%$ ). Of the 423 rodents collected, 328 were tested for evidence of IgG antibodies to New World hantaviruses. Hantavirus antibodies were detected in 34 individuals $(\sim 10 \%)$. This is the first record of hantavirus antibody-positive rodents from the highly urbanized area of North Texas.
\end{abstract}

REsumen.-Entre el 27 de Junio 1997 y el 16 de Mayo 1999, 423 roedores fueron colectados usando trampas Sherman de capturas en vivo (éxito de captura $\sim 22 \%$ ) en el Norte de Texas (condados Collin, Denton, y Grayson). De los 423 roedores colectados, 328 roedores fueron puestos a prueba para evidenciar la presencia de anticuerpos IgG de Hantavirus del Nuevo Mundo. Los anticuerpos de Hantavirus fueron detectados en 34 individuos ( 10\%). Este es el primer registro de roedores con anticuerpo-positivo para Hantavirus de un área altamente urbanizada en el norte de Texas.

Members of the genus Hantavirus are rodent-borne viruses with cosmopolitan distributions (Jonsson et al. 2010). Hantavirus is the only genus within the family Bunyaviridae that does not utilize an arthropod vector; rather, hantaviruses are associated primarily with the rodent families Muridae (Old World) and Cricetidae (New World). Infection in rodent hosts is typically lifelong and thought to be asymptomatic (Mertz et al. 2006). The virus is shed in the saliva, urine, and feces of infected rodents. Both Old World and New World hantaviruses are known to infect humans either by inhalation of infectious aerosols or by direct contact of infectious materials with mucous membranes or broken skin (Vitek et al. 1996).

Six of the 17 North American hantavirus genotypes are associated with Hantavirus Pulmonary Syndrome (HPS; Mills et al. 2009). HPS commonly manifests with fever, headache, myalgia, and nausea (Duchin et al. 1994), followed by rapid onset of severe pulmonary illness (Zaki et al. 1995). HPS frequently concludes with the death of the patient (Nichol et al. 1993, Plyusnin et al. 1996). Between 1993 and 2009, 510 cases of HPS were reported in the United States (MacNeil et al. 2011). Of these cases, 498 $(\sim 98 \%)$ were reported in the western United
States, and of these, $160(\sim 32 \%)$ resulted in death of the patient (MacNeil et al. 2011). Sin Nombre virus (SNV) is reported to be the cause of most HPS cases in the United States (Monroe et al. 1999). SNV is associated principally with Peromyscus maniculatus (Childs et al. 1994), which is a common rodent in rural areas. However, few studies have been conducted to determine hantavirus antibody prevalence in rodents from areas with high human population densities (Calisher et al. 2011).

In January 1997, a fatal case of HPS was reported in Hunt County, Texas (directly east of Collin County; Texas Department of Health 1997), located within the Dallas-Fort Worth Combined Statistical Area (CSA). Given the location of this case, and the paucity of active hantavirus sampling in urban and suburban areas, the purpose of this study was to determine prevalence of hantavirus antibody-positive rodent individuals in areas of high human population within the Dallas-Fort Worth CSA. Trapping efforts focused on the highly populated counties of Collin, Denton, and Grayson in North Texas (Fig. 1). These counties constitute a portion of the Dallas-Fort Worth CSA and have a collective population estimated at over 1.5 million people (U.S. Census Bureau 2010).

\footnotetext{
${ }^{1}$ Junior ROTC Department, Dallas Independent School District, North Dallas High School, 3120 N. Haskell Avenue, Dallas, TX 75204

${ }^{2}$ Department of Biological Sciences, Texas Tech University, Box 43131, Lubbock, TX 79409-3131.

${ }^{3}$ Deceased. Sternberg Museum of Natural History, Fort Hays State University, 3000 Sternberg Drive, Hays, KS 67601.

${ }^{4}$ Corresponding author. E-mail: matt.mauldin@ttu.edu
} 


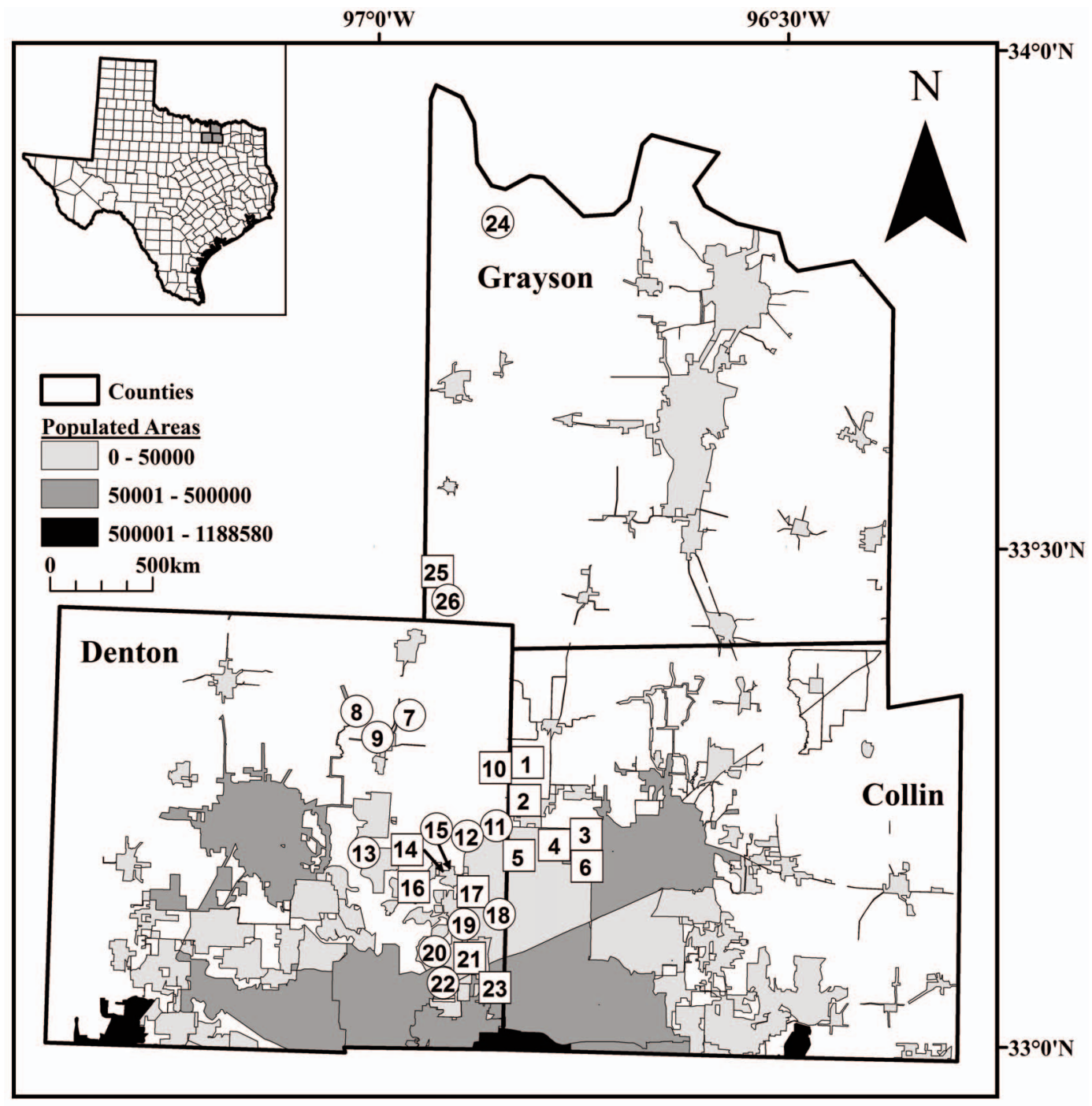

Fig. 1. Study area map of Collin, Denton, and Grayson counties within the Dallas-Fort Worth Combined Statistical Area. Populated areas are shaded according to population estimates of the recent U.S. Census (U.S. Census Bureau 2010). Circles designate collecting localities. Squares designate collecting localities with antibody-positive rodents. Numbers within circles and squares reference locality numbers in Table 1. Inset shows location of study area (grayshaded area) within the state of Texas.

Twenty-six trapping localities (see Fig. 1, Table 1) were selected on the basis of preferred rodent habitat and visible evidence of rodent activity. Trapping localities included open fields and wooded areas within and between urban areas in the study region. Rodents were trapped with Sherman live-traps (H.B. Sherman Traps, Tallahassee, FL) baited with birdseed. Rodents were anesthetized and subsequently euthanized following guidelines set forth by the American Society of
Mammalogists (Animal Care and Use Committee 1998). Blood was collected via capillary tube from the retrorbital capillary plexus of each animal. Sera were separated by centrifugation and frozen at $-70^{\circ} \mathrm{C}$. All individuals collected were prepared as voucher specimens and deposited at the Sternberg Museum of Natural History (SMNH), Hays, Kansas.

Blood samples were sent to the Centers for Disease Control and Prevention (Atlanta, GA) for testing of hantavirus antibodies. Tests were 
TABLE 1. Summary of rodents tested for evidence of IgG antibodies reactant to SNV, from 26 localities in Collin, Denton, and Grayson counties within the Dallas-Fort Worth Combined Statistical Area. Locality numbers correspond to those numbers in Fig. 1. A total of 328 specimens were tested for hantavirus antibodies. Thirty-four specimens were antibody-positive. The numbers of antibody-positive rodents per species by locality is indicated within parentheses. Abbreviations are as follows: Loc. = locality number; Co. = county; COL = Collin County; DN = Denton County; GS $=$ Grayson County; $\mathrm{TN}=$ number of trap-nights; Btay = Baiomys taylori; Mmus = Mus musculus; Opal = Oryzomys palustris; Pleu = Peromyscus leucopus; Pman = Peromyscus maniculatus; Rnor = Rattus norvegicus; Rful = Reithrodontomys fulvescens; and Shis = Sigmodon hispidus .

\begin{tabular}{|c|c|c|c|c|c|c|c|c|c|c|c|}
\hline Loc. & Co. & Specific locality & $\mathrm{TN}$ & Btay & Mmus & Opal & Pleu & Pman & Rnor & Rful & Shis \\
\hline 1 & COL & $3.6 \mathrm{mi}$ NW Prosper & 50 & & & & $3(2)$ & & & & $1(1)$ \\
\hline 2 & COL & $2.1 \mathrm{mi}$ NW Propser & 50 & & & & $4(2)$ & 2 & & & 4 \\
\hline 3 & COL & $5.5 \mathrm{mi} \mathrm{NE}$ Frisco & 200 & 1 & & & 1 & $9(1)$ & & & $3(3)$ \\
\hline 4 & COL & $3.2 \mathrm{mi} \mathrm{SE}$ Prosper & 50 & & & & & 1 & & & $2(1)$ \\
\hline 5 & COL & $10 \mathrm{mi}$ W McKinney & 100 & 1 & 1 & & & 11 & & 3 & $14(1)$ \\
\hline 6 & COL & $5.1 \mathrm{mi}$ SE Prosper & 50 & 1 & & & & 2 & & 1 & $4(2)$ \\
\hline 7 & $\mathrm{DN}$ & $2.5 \mathrm{mi}$ NE Aubrey & 50 & & & & & & & & 1 \\
\hline 8 & $\mathrm{DN}$ & $1.9 \mathrm{mi} \mathrm{NW}$ Aubrey & 50 & & & & 2 & & & & \\
\hline 9 & $\mathrm{DN}$ & $1.6 \mathrm{mi}$ NW Aubrey & 50 & & & & 1 & & & & \\
\hline 10 & $\mathrm{DN}$ & $4.2 \mathrm{mi} \mathrm{SW}$ Celina & 50 & & & & & $3(2)$ & & 2 & $2(1)$ \\
\hline 11 & $\mathrm{DN}$ & $5 \mathrm{mi} \mathrm{N}$ Frisco & 50 & & & & & 3 & & 1 & \\
\hline 12 & $\mathrm{DN}$ & 5 mi NW Frisco & 50 & 1 & & & & 10 & & 3 & \\
\hline 13 & $\mathrm{DN}$ & $10 \mathrm{mi}$ NW The Colony & 50 & & & & & & & & 2 \\
\hline 14 & $\mathrm{DN}$ & $1.8 \mathrm{mi}$ E Little Elm & 50 & 2 & & 1 & 3 & & & & $4(1)$ \\
\hline 15 & $\mathrm{DN}$ & $1.9 \mathrm{mi}$ E Little Elm & 50 & 2 & & & 1 & 3 & & 4 & 4 \\
\hline 16 & $\mathrm{DN}$ & $1 \mathrm{mi}$ E Little Elm & 50 & 1 & & & 1 & 2 & & 1 & $3(3)$ \\
\hline 17 & $\mathrm{DN}$ & 5 mi N The Colony & 100 & & & & & 2 & 2 & & $2(2)$ \\
\hline 18 & $\mathrm{DN}$ & $1.5 \mathrm{mi} \mathrm{W}$ Frisco & 100 & & & & & & & & 15 \\
\hline 19 & $\mathrm{DN}$ & $3.4 \mathrm{mi} \mathrm{N}$ The Colony & 50 & & & & & & & & 1 \\
\hline 20 & $\mathrm{DN}$ & $2 \mathrm{mi}$ W The Colony & 50 & & & & & & & 1 & 1 \\
\hline 21 & $\mathrm{DN}$ & The Colony & 300 & 24 & 4 & & $2(2)$ & $10(1)$ & & 5 & $83(4)$ \\
\hline 22 & $\mathrm{DN}$ & 2 mi SE The Colony & 50 & & & & 1 & & & & \\
\hline 23 & $\mathrm{DN}$ & 3 mi SE The Colony & 50 & & 1 & & & & & & $19(4)$ \\
\hline 24 & GS & 2 mi N Gordonville & 100 & & & & 1 & & & 1 & 4 \\
\hline 25 & GS & $1 \mathrm{mi} \mathrm{W}$ Tioga & 50 & 1 & & & & $4(1)$ & & & 1 \\
\hline 26 & GS & $1 \mathrm{mi}$ S Tioga & 50 & & & & & 7 & & 1 & 3 \\
\hline Totals & & & 1900 & 34 & 6 & 1 & $20(6)$ & $69(5)$ & 2 & 23 & $173(23)$ \\
\hline
\end{tabular}

conducted via enzyme-linked immunosorbent assays (ELISA), following standard protocols (Ksiazek et al. 1995). ELISA methods tested for antibodies reactive to $\mathrm{IgG}$ antibodies of SNV. Because antibody presence is indicative of either current or past infection, such presence may or may not be associated with persistent viral shedding (Calisher et al. 2009). Due to the high cross-reactivity of New World hantavirus antibodies, this assay will detect but not distinguish between antibodies of a wide variety of hantaviruses associated with rodents (Mills et al. 1997).

A total of 423 rodents were trapped during 1900 trap-nights for an overall trap success of 22\%; however, quality blood sera samples were available for only 328 individuals. Thirtyfour of the 328 specimens tested $(\sim 10 \%)$ were determined to have IgG antibodies reactive to SNV. Six Peromyscus leucopus (30\%), 5 P. maniculatus $(\sim 7 \%)$, and 23 Sigmodon hispidus $(\sim 13 \%)$ were antibody positive (Table 1$)$. This is the first documented occurrence of hantavirus antibodies in rodents from the highly urbanized area of North Texas.

As seen in previous studies (Mills et al. 1998, Mantooth et al. 2001), P. leucopus and P. maniculatus both tested positive for hantavirus antibodies. Peromyscus maniculatus is the primary reservoir of SNV and Monongahela virus (MGLV). SNV is the leading cause of HPS (Monroe et al. 1999), and MGLV has also been associated with HPS (Song et al. 1996). Peromyscus leucopus is both a known reservior for New York virus (NYV; Hjelle et al. 1995) and a host to Blue River virus (BRV; Morzunov et al. 1998). Although NYV has been associated with HPS, BRV has not. The third antibody-positive rodent species in this study was S. hispidus, a known reservoir for Black Creek Canal virus (BCCV; Rollin et al. 1995) and host to Muleshoe virus (MSV; Rawlings et al. 1996). Because of the ability of all antibody-positive rodent species to harbor 
multiple hantavirus species, amplification and sequencing of the viral genome would be necessary to confirm the specific identification of the virus.

None of the 5 remaining species collected in this study (Baiomys taylori, Mus musculus, Oryzomys palustris, Rattus norvegicus, and Reithrodontomys fulvescens) tested positive for IgG antibodies to hantavirus, though these species have been reported to be antibody positive in previous studies (LeDuc et al. 1986, Childs et al. 1994, McIntyre et al. 2005). Two of these species, O. palustris and $R$. norvegicus, are reservoirs for hantaviruses with known human health implications in North America (Lee et al. 1982, LeDuc et al. 1986, Hjelle et al. 1996, Ksiazek et al. 1997). It is not clear whether the failure to identify antibodypositive rodents of these species was a result of small sample size (Table 1) or the "dilution effect" (Ostfeld and Keesing 2000). The "dilution effect" is a phenomenon in which increased rodent biodiversity is correlated negatively with virus antibody prevalence within rodent communities. Previous studies have determined increased species diversity to have a negative effect on both abundance of reservoir hosts and their infection prevalence with hantavirus (Dizney and Ruedas 2009, Suzán et al. 2009). Localities where at least one of these species was collected had an average species richness of $\sim 3.6$ species (range 2-6 species) per locality (Table 1); however, more stringent trapping protocols would be necessary to accurately estimate measures of biodiversity.

Of the 2 reservoir species with human health implications in North America, O. palustris is the principal reservoir for Bayou virus (BAYV; Hjelle et al. 1996, Ksiazek et al. 1997), which is thought to be the second leading cause of HPS in the United States (Morzunov et al. 1995). The distribution of $O$. palustris includes the majority of the southeastern United States, encompassing numerous metropolitan areas (Wilson and Reeder 2005); however, due to the non-peridomestic behavior of $O$. palustris, the risk of human infection is relatively low (McIntyre et al. 2005). The second species, $R$. norvegicus, is associated with Seoul virus (SEOV; Lee et al. 1982, LeDuc et al. 1986), which has been linked to Hemorrhagic Fever with Renal Syndrome (HFRS; LeDuc et al. 1982). Rattus norvegicus is an invasive, commensal species that occurs commonly in urban areas (Hall 1981). LeDuc et al. (1986) screened $1616 R$. norvegicus from all continents, excluding Antarctica, and 341 individuals $(\sim 21 \%)$ tested positive for hantavirus antibodies. The city of Baltimore, Maryland, had the highest prevalence, with 108 of 170 screened individuals ( $64 \%)$ testing positive. In addition, Baltimore recently had a domestically acquired case of HFRS due to SEOV (Woods et al. 2009). Given the human health implications of these case studies, the results presented herein warrant further rodent sampling for hantavirus screening in the Dallas-Fort Worth CSA, as well as other urbanized areas.

We thank Curtis Schmidt at the Sternberg Museum for help accessing records of cataloged specimens. We also thank the Centers for Disease Control and Prevention for funding and performing ELISA assays. Comments from Robert Bradley and 2 anonymous reviewers improved the manuscript. Nicté Ordóñez-Garza provided the Spanish abstract translation.

\section{Literature Cited}

Animal Care and Use Committee. 1998. Guidelines for the capture, handling, and care of mammals as approved by the American Society of Mammalogists. Journal of Mammalogy 79:1416-1431.

Calisher, C.H., J.N. Mills, J.J. Root, J.B. Doty, and B.J. BEATy. 2011. The relative abundance of deer mice with antibody to Sin Nombre virus corresponds to the occurrence of hantavirus pulmonary syndrome in nearby humans. Vector-Borne and Zoonotic Diseases 11:577-582.

Calisher, C.H., C.J. Peters, R.J. Douglass, and A.J. KuENZI. 2009. Hantaviral infections of rodents: possible scenarios. Archives of Virology 154:1195-1197.

Childs, J.E., T.G. KsiazeK, C.F. Spiropoulou, J.W. Krebs, S. Morzunov, G.O. Maupin, K.L. Gage, P.E. Rollin, J. Sarisky, R.E. Enscore, et al. 1994. Serologic and genetic identification of Peromyscus maniculatus as the primary rodent reservoir for a new hantavirus in the southwestern United States. Journal of Infectious Diseases 169:1271-1280.

Dizney, L.J., AND L.A. Ruedas. 2009. Increased host species diversity and decreased prevalence of Sin Nombre virus. Emerging infectious diseases 15: 1012-1018.

Duchin, J.S., F.T. Koster, C.J. Peters, G.L. Simpson, B. Tempest, S.R. Zaki, T.G. Ksiazek, P.E. Rollin, S. Nichol, E.T. UmLand, ET AL. 1994. Hantavirus pulmonary syndrome: a clinical description of 17 patients with a newly recognized disease. New England Journal of Medicine 330:949-955.

HaLL, E.R. 1981. The mammals of North America. 2nd edition. Wiley \& Sons, New York, NY. 
Hjelle, B., D. Goade, N. Torrez-Martinez, M. LangWilliams, J. Kim, R.L. HaRRIS, aND J.A. RaWLings. 1996. Hantavirus pulmonary syndrome, renal insufficiency, and myositis associated with infection by Bayou hantavirus. Clinical Infectious Diseases 23: 495-500.

Hjelle, B., J. Krolikowski, N. Torrez-Martinez, F. Chavez-Giles, C. Vanner, and E. Laposata. 1995. Phylogenetically distinct hantavirus implicated in a case of hantavirus pulmonary syndrome in the northeastern United States. Journal of Medical Virology 46:21-27.

Jonsson, C.B., L.T.M. Figueiredo, and O. Vapalahti. 2010. A global perspective on hantavirus ecology, epidemiology, and disease. Clinical Microbiology Reviews 23:412-441.

Ksiazek, T.G., S.T. Nichol, J.N. Mills, M.G. Groves, A. WozniaK, S. MCADAMS, M.C. Monroe, A.M. Johnson, M.L. Martin, C.J. Peters, and P.E. Rollin. 1997. Isolation, genetic diversity, and geographic distribution of Bayou virus (Bunyaviridae: Hantavirus). American Journal of Tropical Medicine and Hygiene 57:445-448.

KsiazeK, T.G., C.J. Peters, P.E. Rollin, S. Zaki, S. Nichol, C. Spiropoulou, S. Morzunov, H. Feldmann, A. Sanchez, and A.S. Khan. 1995. Identification of a new North American hantavirus that causes acute pulmonary insufficiency. American Journal of Tropical Medicine and Hygiene 52: $117-123$.

LeDuc, J.W., G.A. Smith, L.R. Bagley, S.E. Hasty, And K.M. Johnson. 1982. Preliminary evidence that Hantaan or a closely related virus is enzootic in domestic rodents. New England Journal of Medicine 307:624.

LeDuc, J.W., G.A. Smith, J.E. Childs, F.P. Pinheiro, J.I. Maiztegui, B. Niklasson, A. Antoniades, D.M. Robinson, M. Khin, K.F. Shortridge, et AL. 1986. Global survey of antibody to Hantaan-related viruses among peridomestic rodents. Bulletin of the World Health Organization 64:139-144.

LEE, H.W., L.J. BAEK, AND K.M. JoHnson. 1982. Isolation of Hantaan virus, the etiologic agent of Korean hemorrhagic fever, from wild urban rats. Journal of Infectious Diseases 146:638-644.

MacNeil, A., T.G. KsiazeK, and P.E. Rollin. 2011. Hantavirus pulmonary syndrome, United States, 19932009. Emerging Infectious Diseases 17:1195-1201.

Mantooth, S.J., M.L. Milazzo, R.D. Bradley, C.L. Hice, G. Ceballos, R.B. Tesh, and C.F. Fulhorst. 2001. Geographical distribution of rodent-associated hantaviruses in Texas. Journal of Vector Ecology 26:7-14.

McIntyre, N.E., Y. Chu, R.D. Owen, A. AbuZeineh, N. De La Sancha, C.W. Dick, T. Holsomback, R.A. NisBetT, AND C. JonsSON. 2005. A longitudinal study of Bayou virus, hosts, and habitat. American Journal of Tropical Medicine and Hygiene 73:1043-1049.

Mertz, G.J., B. Hjelle, and M. Crowley. 2006. Diagnosis and treatment of New World hantavirus infections. Current Opinion in Infectious Diseases 19: $437-442$.

Mills, J.N., B.R. Amman, and G.E. Glass. 2009. Ecology of hantaviruses and their hosts in North America. Vector-Borne and Zoonotic Diseases 10:563-574.

Mills, J.N., J.M. Johnson, T.G. KsiaZeK, B.A. Ellis, P.E. Rollin, T.L. Yates, M.O. Mann, M.R. Johnson,
M.L. Campbell, J. Miyashiro, et al. 1998. A survey of hantavirus antibodies in small-mammal populations in selected United States national parks. American Journal Tropical Medicine and Hygiene 58: $525-532$

Mills, J.N., T.G. Kziazek, B.A. Ellis, P.E. Rollin, S.T. Nichol, T.L. Yates, W.L. Gannon, C.E. Levy, D.M. Engelthaler, T. Davis, et AL. 1997. Patterns of association with host and habitat: antibody reactive with Sin Nombre virus in small mammals in the major biotic communities of southwestern United States. American Journal of Tropical Medicine and Hygiene 56:273-284.

Monroe, M.C., S.P. Morzunov, A.M. Johnson, M.D. Bowen, H. Artsob, T. Yates, C.J. Peters, P.E. Roldin, T.G. KsiazeK, AND S.T. NiCHOL. 1999. Genetic diversity and distribution of Peromyscus-borne hantaviruses in North America. Emerging Infectious Diseases 5:75-86.

Morzunov, S.P., H. Feldmann, C.F. Spiropoulou, V.A. Semenova, P.E. Rollin, T.G. Ksiazek, C.J. Peters, AND S.T. NiCHOL. 1995. A newly recognized virus associated with a fatal case of hantavirus pulmonary syndrome in Louisiana. Journal of Virology 69:1980-1983.

Morzunov, S.P., J.E. Rowe, T.G. Ksiazek, C.J. Peters, S.C. ST. JEOR, and S.T. NiCHOL. 1998. Genetic analysis of the diversity and origin of hantaviruses in Peromyscus leucopus mice in North America. Journal of Virology 72:57-64.

Nichol, S.T., C.F. Spiropoulou, S. Morzunov, P.E. Rollin, T.G. Ksiazek, H. Feldmann, A. Sanchez, J. Childs, S. Zaki, and C.J. Peters. 1993. Genetic identification of a hantavirus associated with an outbreak of acute respiratory illness. Science 262: 914-918.

Ostfeld, R.S., And F. KeEsing. 2000. Biodiversity and disease risk: the case of Lyme disease. Conservation Biology 14:722-728.

Plyusnin, A., O. Vapalahti, and A. Vaheri. 1996. Hantaviruses: genome structure, expression, and evolution. Journal of General Virology 77:2677-2687.

Rawlings J.A., N. TorRez-Martinez, S.U. Neill, G.M. Moore, B.N. Hicks, S. Pichuantes, A. Nguyen, M. Bharadwaj, and B. Hjelle. 1996. Cocirculation of multiple hantaviruses in Texas, with characterization of the small (S) genome of a previously undescribed virus of cotton rats (Sigmodon hispidus). American Journal of Tropical Medicine and Hygiene 55:672-679.

Rollin, P.E., T.G. Ksiazek, L.H. Elliot, E.V. Ravkov, S. Morzunov, W. Livingstone, M. Monroe, G. Glass, S. RuO, A.S. Khan, ET AL. 1995. Isolation of Black Creek Canal virus, a new hantavirus from Sigmodon hispidus in Florida. Journal of Medical Virology 46:35-39

Song, J.W., L.J. Baek, J.W. Nagle, D. Schlitter, and R. YANAGIHARA. 1996. Genetic and phylogenetic analyses of hantaviral sequences amplified from archival tissues of deer mice (Peromyscus maniculatus nubiterrae) captured in the eastern United States. Archives of Virology 141:959-967.

SuzÁn, G., E. Marcé, J.T. Giermakowski, J.N. Mills, G. Ceballos, R.S. Ostfeld, B. Armién, J.M. PasCALE, AND T.L. YATES. 2009. Experimental evidence for reduced rodent diversity causing increased hantavirus prevalence. PloS One 4:e5461. 
Texas Department of Health. 1997. Epidemiology in Texas 1997 Annual Report. Austin, TX.

U.S. Census Bureau. 2010. State and county quickfacts. [Cited 7 May 2012]. Available from: http://quickfacts .census.gov/qfd/states/48000.html

Vitek, C.R., R.F. Breiman, T.G. Ksiazek, P.E. Rollin, J.C. Mclaughlin, E.T. Umland, K.B. Nolte, A. Loera, C.M. Sewell, and C.J. Peters. 1996. Evidence against person-to-person transmission of hantavirus to health care workers. Clinical Infectious Diseases 22:824-826.

Wilson, D.E., And D.M. ReEder. 2005. Mammal species of the world: a taxonomic and geographic reference. 3rd edition. Johns Hopkins University Press, Baltimore, MD.
Woods, C., R. Palekar, P. Kim, D. Blythe, O. De SenarClens, K. Feldman, E.C. Farnon, P.E. Rollin, C.G. Albariño, S.T. Nichol, and M. SMith. 2009. Domestically acquired Seoul virus causing Hemorrhagic Fever with Renal Syndrome-Maryland, 2008. Clinical Infectious Diseases 49:109-112.

ZaKi, S.R., P.W. Greer, L.M. Coffield, C.S. Goldsmith, K.B. Nolte, K. Foucar, R.M. Feddersen, R.E. Zumwalt, G.L. Miller, A.S. Khan, et al. 1995. Hantavirus pulmonary syndrome: pathogenesis of an emerging infectious disease. American Journal of Pathology 146:552-579.

Received 13 June 2012 Accepted 29 May 2013 